\title{
Effect of Adenovirus Infection on Expression of Human Histone Genes
}

\author{
S. J. FLINT,${ }^{1 *}$ M. A. PLUMB, ${ }^{2}$ UENG-CHENG YANG, ${ }^{1}$ G. S. STEIN, ${ }^{2}$ AND J. L. STEIN ${ }^{2}$ \\ Molecular Biology, Princeton University, Princeton, New Jersey 08544, ' and University of Florida College of Medicine, \\ Gainesville, Florida $32610^{2}$
}

Received 19 March 1984/Accepted 19 April 1984

\begin{abstract}
The influence of adenovirus type 2 infection of HeLa cells upon expression of human histone genes was examined as a function of the period of infection. Histone RNA synthesis was assayed after run-off transcription in nuclei isolated from mock-infected cells and after various periods of adenovirus infection. Histone protein synthesis was measured by $\left[{ }^{3} \mathrm{H}\right]$ leucine labeling of intact cells and fluorography of electrophoretically fractionated nuclear and cytoplasmic proteins. The cellular representation of RNA species complementary to more than 13 different human histone genes was determined by RNA blot analysis of total cellular, nuclear or cytoplasmic RNA by using a series of ${ }^{32}$ P-labeled cloned human histone genes as hybridization probes and also by analysis of ${ }^{3} \mathrm{H}$-labeled histone mRNA species synthesized in intact cells. By $18 \mathrm{~h}$ after infection, HeLa cell DNA synthesis and all parameters of histone gene expression, including transcription and the nuclear and cytoplasmic concentrations of core and H1 mRNA species, were reduced to less than 5 to $10 \%$ of the control values. By contrast, transcription and processing of other cellular mRNA sequences have been shown to continue throughout this period of infection. The early period of adenovirus infection was marked by an inhibition of transcription of histone genes that accompanied the reduction in rate of HeLa cell DNA synthesis. These results suggest that the adenovirus-induced inhibition of histone gene expression is mediated in part at the transcriptional level. However, the persistence of histone mRNA species at concentrations comparable to those of mock-infected control cells during the early phase of the infection, despite a reduction in histone gene transcription and histone protein synthesis, implies that histone gene expression is also regulated posttranscriptionally in adenovirus-infected cells. These results suggest that the tight coupling between histone mRNA concentrations and the rate of cellular DNA synthesis, observed when DNA replication is inhibited by a variety of drugs, is not maintained after adenovirus infection.
\end{abstract}

Infection of human cells by adenovirus results in a complex and interdependent series of biochemical and molecular events leading to production of progeny virus. Our understanding of the expression of virus-encoded genes is well established (see references 14,47 , and 50 for reviews), but far less is known about the molecular mechanisms that permit the virus to usurp the biosynthetic machinery of the host cell, ultimately causing its death (S. J. Flint in $\mathrm{H}$. Fraenkel-Conrat and R. R. Wagner, ed., Comprehensive Virology, in press). Such mechanisms include the selective translation of viral mRNA species during the late phase of infection, mediated at least in part by VA-RNA $A_{I}(48)$, and the inhibition of appearance in the cytoplasm of newly synthesized cellular mRNA sequences $(3,5,11,16,55)$. Neither transcription nor processing of cellular pre-mRNA has been observed to be inhibited during the late phase of adenovirus infection. These observations imply that adenovirus infection disrupts some late, nonenzymatic processing step in the production of mature, cellular mRNA species within the nucleus or their translocation to the cytoplasm (Flint, in press). Studies of the expression of individual cellular genes in adenovirus-infected cells have, to date, been limited to those whose transcripts are subject to extensive processing, including the creation of mature polyadenylated 3 ' termini and splicing to remove intervening sequences. It was, therefore, of some interest to examine the effects of adenovirus infection upon expression of mRNA species that do not undergo extensive post-transcriptional modifications, such as histone mRNAs.

\footnotetext{
* Corresponding author.
}

Structural analysis of human histone genes has indicated that they are anatomically and functionally uncomplicated, lacking intervening sequences and polyadenylate tracts $(10$, $20,40,41)$. Moreover, histone mRNA species can be found in functional form in polyribosomes within minutes of transcription of histone genes (reviewed in reference 46). Expression of most $(1,4,6,7,9,13,20-22,24,32,36,38,39$, $42,44,45)$, though not all $(12,18,26,53)$, histone genes has been shown to be temporally and functionally coupled to DNA replication. Adenovirus infection of permissive cells induces complete, and quite rapid, inhibition of cellular DNA synthesis, concomitant with the initiation and acceleration of viral DNA replication $(17,23)$. It therefore seemed possible that histone gene expression might be profoundly influenced in infected cells by mechanisms distinct from those that mediate inhibition of expression of other cellular genes.

To obtain a better understanding of the range of mechanisms whereby adenovirus infection might modulate cellular gene expression, we systematically examined the influence of adenovirus type 2 (Ad2) infection upon various parameters of human histone gene expression in HeLa cells.

\section{MATERIALS AND METHODS}

Cells and virus. HeLa cells were maintained in suspension culture at densities of $2 \times 10^{5}$ to $4 \times 10^{5}$ cells per ml, in SMEM (GIBCO Diagnostics) supplemented with $5 \%$ calf serum. Ad2 stocks were prepared after low-multiplicity infection of HeLa cells as described previously (15) and titrated on HeLa cells by the method of Williams (52). 
Infection and labeling of HeLa cells. Large (2- to 6-liter) cultures of actively growing HeLa cells were concentrated to $1 / 10$ the initial culture volume and infected with Ad2 at 50 or $100 \mathrm{PFU}$ per cell. After adsorption at $37^{\circ} \mathrm{C}$ for $1 \mathrm{~h}$, infected cultures were diluted to the original volume with fresh SMEM supplemented with $2 \%$ calf serum and $2 \mathrm{mM}$ glutamine. Portions of the culture were withdrawn after concentration but before infection and after various periods of incubation at $37^{\circ} \mathrm{C}$, as indicated in the figure legends.

Uninfected and infected cells were labeled after 10 -fold concentration with $20 \mu \mathrm{Ci}$ of $\left[{ }^{3} \mathrm{H}\right]$ leucine $(40$ to $60 \mathrm{Ci} / \mathrm{mol}$ ) per ml for $2 \mathrm{~h}$ at $37^{\circ} \mathrm{C}$, with $50 \mu \mathrm{Ci}$ of $\left[{ }^{3} \mathrm{H}\right]$ thymidine $(50$ to 80 $\mathrm{Ci} / \mathrm{mol}$; New England Nuclear) per $\mathrm{ml}$ for $1 \mathrm{~h}$ at $37^{\circ} \mathrm{C}$, or with $150 \mu \mathrm{Ci}$ of $\left[{ }^{3} \mathrm{H}\right]$ uridine $(35$ to $50 \mathrm{Ci} / \mathrm{mol}$; New England Nuclear) per $\mathrm{ml}$ for $2 \mathrm{~h}$ at $37^{\circ} \mathrm{C}$. At the end of the labeling period, each batch of cells was harvested by centrifugation, washed once in ice-cold isotonic buffer ( $30 \mathrm{mMTris}$-hydrochloride [pH 7.9] containing $0.125 \mathrm{M} \mathrm{KCl}$ and $5 \mathrm{mM} \mathrm{MgCl}_{2}$ ), and stored at $-20^{\circ} \mathrm{C}$ until the end of the infection.

Isolation of total cellular RNA. Cells $\left(5 \times 10^{7}\right)$ were lysed in $4.5 \mathrm{ml}$ of $1.3 \mathrm{mM}$ Tris-hydrochloride ( $\mathrm{pH} 7.4$ ) containing 0.7 mM EDTA, 2.4\% (wt/vol) sodium dodecyl sulfate (SDS), and $0.9 \mathrm{mg}$ of proteinase $\mathrm{K}$ per $\mathrm{ml}$. After a 15 -min incubation at room temperature and the addition of $0.3 \mathrm{ml}$ of a $5 \mathrm{M} \mathrm{NaCl}$ solution, the aqueous phase was extracted twice with 2 volumes of buffered phenol:chloroform:isoamyl alcohol (25:24:1 [ $\mathrm{vol} / \mathrm{vol} / \mathrm{vol}]$ and once with 1 volume of chloroform: isoamyl alcohol (24:1 [ $\mathrm{vol} / \mathrm{vol}])$. Nucleic acids were precipitated with 3 volumes of ethanol at $-20^{\circ} \mathrm{C}$ in the presence of $53 \mathrm{mM}$ potassium acetate.

Nucleic acids were recovered by centrifugation, suspended in $2 \mathrm{ml}$ of $10 \mathrm{mM}$ Tris-hydrochloride ( $\mathrm{pH} \mathrm{7.4)-2} \mathrm{mM}$ $\mathrm{CaCl}_{2}-10 \mathrm{mM} \mathrm{MgCl}{ }_{2}$ and incubated at $37^{\circ} \mathrm{C}$ for $20 \mathrm{~min}$ in the presence of $0.1 \mathrm{mg}$ of DNase I per ml (electrophoretically pure; Sigma Chemical Co.) which had been pretreated with proteinase $\mathrm{K}$ for $2 \mathrm{~h}$ as described by Tullis and Rubin (51). After addition of 0.05 volumes of $5 \mathrm{M} \mathrm{NaCl}$ and 0.25 volumes of $10 \%$ (wt/vol) SDS, the RNA solution was extracted with phenol and chloroform and ethanol precipitated as described above.

Northern blot analysis of cellular RNA. Cellular RNA preparations $(50 \mu \mathrm{g})$ were resolved electrophoretically in a $1.5 \%(\mathrm{wt} / \mathrm{vol})$ agarose gel containing $6 \%(\mathrm{wt} / \mathrm{vol})$ formaldehyde as described previously (37) except that $3.7 \%(\mathrm{wt} / \mathrm{vol})$ formaldehyde-20 mM MOPS (morpholinepropanesulfonic acid) ( $\mathrm{pH} 7.0)-5 \mathrm{mM}$ sodium acetate-1 mM EDTA was used as the electrolyte. RNA was transferred to nitrocellulose filters by diffusion in $20 \times \operatorname{SSC}(3 \mathrm{M} \mathrm{NaCl}$ plus $0.3 \mathrm{M}$ sodium citrate, $\mathrm{pH} 7.0$ ), and the filters were baked in vacuo for $2 \mathrm{~h}$ at $80^{\circ} \mathrm{C}(49)$.

Filters were prehybridized at 40 to $50^{\circ} \mathrm{C}$ for 5 to $6 \mathrm{~h}$ in hybridization buffer, $50 \%$ (wt/vol) formamide-5 $\times$ SSC-100 $\mu \mathrm{g}$ of Escherichia coli DNA per ml-5× Denhardt solution (100× Denhardt solution is $2 \%$ [wt/vol] polyvinylpyrrolidone, $2 \%$ [wt/vol] Ficoll, $2 \%$ [wt/vol] bovine serum albumin). Hybridization was performed at 40 to $50^{\circ} \mathrm{C}$ for 36 to 72 $h$ in hybridization buffer containing $10^{6} \mathrm{cpm}$ of thermally denatured probe per $\mathrm{ml}$. The probe was prepared by nick translation with $\left[\alpha-{ }^{32} \mathrm{P}\right] \mathrm{dCTP}$ as described by Maniatis et al. (31). Filters were washed at $60^{\circ} \mathrm{C}$ for $30 \mathrm{~min}$ with $125 \mathrm{ml}$ of each of the following: (i) twice with $5 \times \mathrm{SSC}-\mathrm{l} \times$ Denhardt solution; (ii) twice with $2 \times \mathrm{SSC}-0.1 \%$ (wt/vol) SDS; (iii) twice with $1 \times$ SSC-0.1\% (wt/vol) SDS. Filters were exposed to preflashed XAR5 X-ray films at $-20^{\circ} \mathrm{C}$ for 1 to 3 days in cassettes containing Kodak Regular intensifying screens. Hybridization was quantitated by densitometry or by liquid scintillation spectrometry or by both. Quenching was corrected by external standardization.

Hybrid selection of $\left[{ }^{3} \mathbf{H}\right]$ uridine-labeled total cellular RNA. Restriction endonuclease-digested plasmid DNA (50 $\mu \mathrm{g})$ was denatured in $0.3 \mathrm{M} \mathrm{NaOH}$ and bound to nitrocellulose filters (Millipore GSWP01300) in $0.15 \mathrm{M} \mathrm{NaOH}-1 \mathrm{M}$ ammonium acetate as described previously (34). Filters were pretreated at $45^{\circ} \mathrm{C}$ for $20 \mathrm{~h}$ in hybridization buffer $(50 \%$ [wt/vol] formamide, $0.5 \%$ [wt/vol] SDS, $0.5 \mathrm{M} \mathrm{NaCl}, 1 \mathrm{mM}$ EDTA, $25 \mathrm{mM}$ HEPES [ $N$-2-hydroxyethylpiperazine- $N^{\prime}$-2-ethanesulfonic acid] [pH 7.0], containing $100 \mu \mathrm{g}$ of thermally denatured $E$. coli DNA per $\mathrm{ml}$ ). Filters were washed and eluted before hybridization as described below. After preequilibration with hybridization buffer for $60 \mathrm{~min}$, filters were hybridized at $45^{\circ} \mathrm{C}$ for $20 \mathrm{~h}$ with $200 \mu$ l of hybridization buffer containing $0.75 \mathrm{mg}$ of ${ }^{3} \mathrm{H}$-labeled total cellular RNA per ml. Filters were then washed with $0.5 \mathrm{ml}$ of each of the following solutions for $10 \mathrm{~min}$ : (i) twice with hybridization buffer at $50^{\circ} \mathrm{C}$; (ii) twice with $0.5 \mathrm{M} \mathrm{NaCl}-1 \mathrm{mM}$ EDTA-25 $\mathrm{mM}$ HEPES (pH 7.0)-0.5\% (wt/vol) SDS at room temperature; (iii) three times with $0.1 \times \mathrm{SSC}-0.5 \%(\mathrm{wt} / \mathrm{vol}) \mathrm{SDS}$ at $60^{\circ} \mathrm{C}$; (iv) three times with $10 \mathrm{mM} \operatorname{HEPES}$ (pH 7.0) at room temperature. RNA was eluted three times with $100 \mu$ l of $90 \%$ formamide-0.5 M NaCl-1 mM EDTA-25 mM HEPES (pH 7.0) at $72^{\circ} \mathrm{C}$ for $5 \mathrm{~min}$. The pooled eluates were diluted by adding 1 volume of a solution containing $0.2 \mathrm{M} \mathrm{NaCl}$ and $0.34 \mu \mathrm{g}$ of yeast tRNA per $\mathrm{ml}$ and ethanol precipitated at $-70^{\circ} \mathrm{C}$. The RNA was recovered by centrifugation and electrophoretically resolved on $6 \%(\mathrm{wt} / \mathrm{vol})$ polyacrylamide$50 \%$ (wt/vol) urea gels electrophoresed with a surface temperature of 50 to $60^{\circ} \mathrm{C}$ as described by Plumb et al. (34). Gels were soaked in $\mathrm{En}^{3}$ Hance (New England Nuclear) for $1 \mathrm{~h}$ and then in water for $1 \mathrm{~h}$ and dried for fluorography with preflashed XAR5 X-ray film at $-70^{\circ} \mathrm{C}$ for 3 to 80 days.

Transcription in isolated nuclei. Nuclei were isolated from $10^{8}$ mock- or Ad2-infected HeLa cells as described previously (54). Isolated nuclei were counted, and equal numbers from each batch of cells were incubated at $37^{\circ} \mathrm{C}$ for $30 \mathrm{~min}$ in $1 \mathrm{ml}$ of $0.03 \mathrm{M}$ Tris-hydrochloride containing $5 \mathrm{mM} \mathrm{MgCl}_{2}, 1$ $\mathrm{mM} \mathrm{MnCl} 2,0.07 \mathrm{M}\left(\mathrm{NH}_{4}\right)_{2} \mathrm{SO}_{4}, 2 \mathrm{mM}$ dithiothreitoli, $25 \%$ (wt/vol) glycerol, $1 \mathrm{mM}$ ATP, $0.25 \mathrm{mM}$ each of CTP and UTP, and $100 \mu \mathrm{Ci}$ of $\left[\alpha-{ }^{32} \mathrm{P}\right] \mathrm{GTP}(760 \mathrm{Ci} / \mathrm{mmol}$; New England Nuclear). At the end of the reaction, nuclei were lysed by addition of $\mathrm{NaCl}$ to $0.5 \mathrm{M}$ and RNA purified after digestion with DNase I (electrophoretically purified, Worthington Diagnostics) as described above. After ethanol precipitation, the RNA was collected, dissolved in $0.5 \mathrm{ml}$ of 0.01 M Tris-hydrochloride ( $\mathrm{pH}$ 7.4) containing 2 mM EDTA, heated at $70^{\circ} \mathrm{C}$ for $10 \mathrm{~min}$, and hybridized to nitrocellulose filters to which restriction endonuclease fragments of Ad2 DNA or human histone DNA had been transferred by the method of Southern (43). Prehybridization and hybridization were at $68^{\circ} \mathrm{C}$ as described previously (16). After hybridization, the filters were washed twice in $2 \times \mathrm{SSC}$ at $65^{\circ} \mathrm{C}$ and then incubated with $25 \mu \mathrm{g}$ of RNase $\mathrm{A}$ at $25^{\circ} \mathrm{C}$ for $30 \mathrm{~min}$. The filters were rinsed at room temperature with several changes of $2 \times$ SSC, air dried, and exposed to Kodak X/AR or $\mathrm{X} / \mathrm{RP}$ film at room temperature.

Hybridization of labeled DNA to Ad2 DNA. Nitrocellulose filters carrying 0.5 to $10 \mu \mathrm{g}$ of denatured Ad2 DNA or $2 \mu \mathrm{g}$ of denatured pBR322 DNA were prepared as described above. Filters were prehybridized in $0.01 \mathrm{M}$ Tris-hydrochloride ( $\mathrm{pH}$ 7.4) containing $1 \mathrm{mM}$ EDTA, $12.5 \mathrm{mM}$ sodium $\mathrm{PP}_{\mathrm{i}}, 1 \mathrm{M}$ $\mathrm{NaCl}, 0.1 \%$ (wt/vol) SDS, $5 \times$ Denhardt solution, and $25 \mu \mathrm{g}$ of denatured, fragmented salmon sperm DNA per ml for $16 \mathrm{~h}$ at $68^{\circ} \mathrm{C}$. Filters were removed from this solution, air dried, 
and placed in individual vials containing $1 \mathrm{ml}$ of a hybridization solution identical to that used during prehybridization except that the concentrations of Denhardt solution and salmon sperm DNA were reduced to $2.5 \times$ and $10 \mu \mathrm{g} / \mathrm{ml}$, respectively. Total DNA was purified (by the method of Botchan et al. [8]) from uninfected or infected cells that had been labeled with $\left[{ }^{3} \mathrm{H}\right]$ thymidine. After ethanol precipitation, the DNA was collected and dissolved in a small volume of $0.01 \mathrm{M}$ Tris-hydrochloride ( $\mathrm{pH}$ 7.4) containing $1 \mathrm{mM}$ EDTA. Equal amounts of labeled DNA from each batch of cells were then hybridized, after denaturation in $0.3 \mathrm{M} \mathrm{NaOH}$ at $37^{\circ} \mathrm{C}$ for $15 \mathrm{~min}$, to filters containing pBR322 DNA or increasing quantities of Ad2 DNA. All hybridization reactions were performed in duplicate, and incubation at $68^{\circ} \mathrm{C}$ was for 40 to $48 \mathrm{~h}$. Filters were then washed as follows: once with hybridization solution for $30 \mathrm{~min}$ at $65^{\circ} \mathrm{C}$. twice with $2 \times$
SSC for $30 \mathrm{~min}$ at $65^{\circ} \mathrm{C}$, twice with $0.2 \times \mathrm{SSC}$ containing $0.1 \%(\mathrm{wt} / \mathrm{vol}) \mathrm{SDS}$ for $30 \mathrm{~min}$ at $60^{\circ} \mathrm{C}$, and twice with $2 \times$ $\mathrm{SSC}$ at room temperature. Filters were dried and counted in Econofluor (New England Nuclear).

Analysis of proteins synthesized in Ad2-infected cells. Preparation of nuclear and cytoplasmic extracts of samples of cells harvested before or after various periods of infection. electrophoretic separation of proteins, and fluorography were performed as described previously $(5,11)$.

\section{RESULTS}

Levels of histone mRNA species in Ad2-infected HeLa S3 cells. Initially, the steady-state concentrations of core $(\mathrm{H} 2 \mathrm{~A}$. $\mathrm{H} 2 \mathrm{~B}, \mathrm{H} 3$, and $\mathrm{H} 4$ ) histone mRNA species were examined in adenovirus-infected HeLa cells to investigate the nature of any Ad2-induced perturbation of histone gene expression.
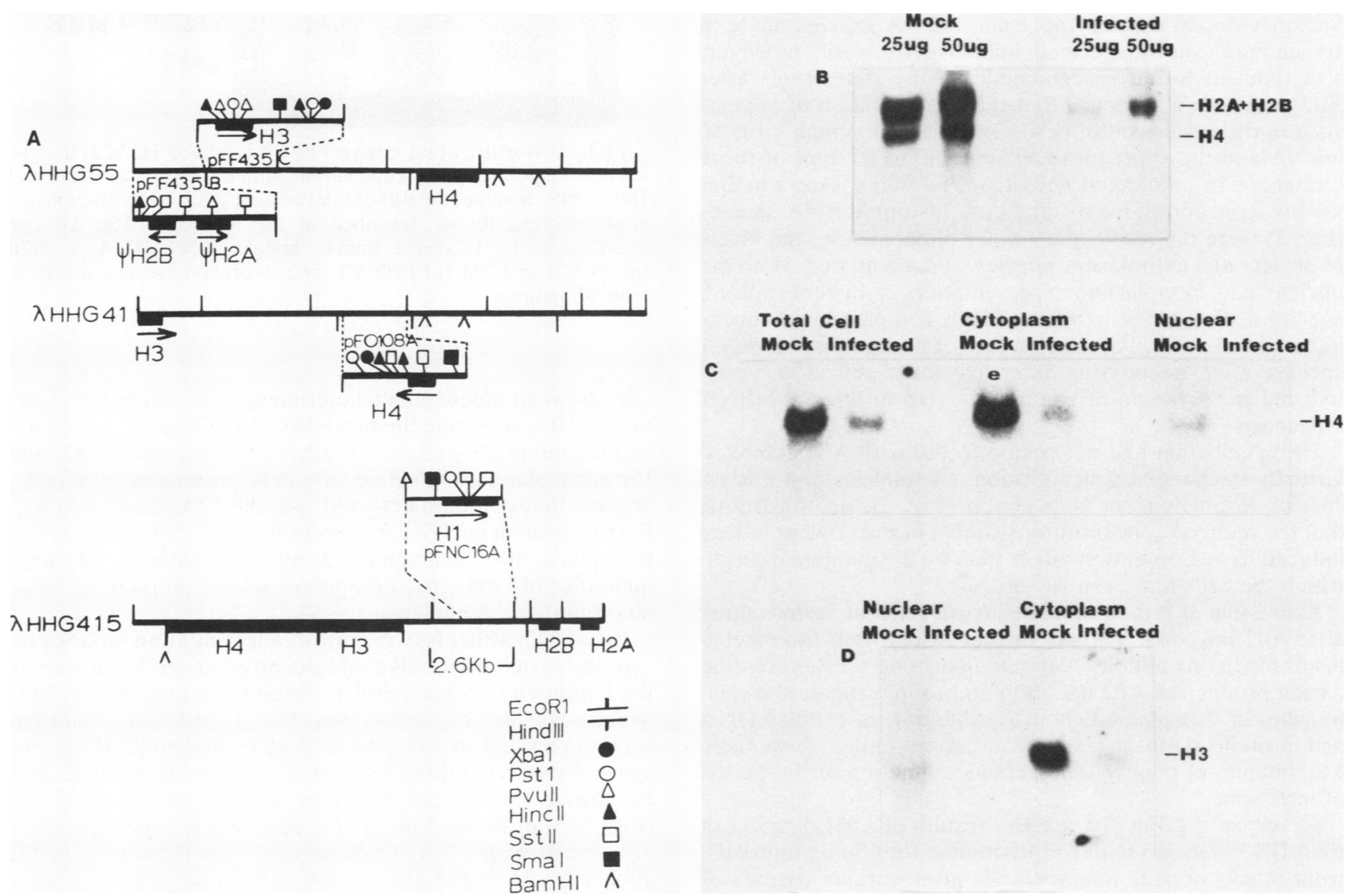

FIG. 1. (A) Restriction endonuclease maps of cloned human histone genes used as hybridization probes. The isolation and characterization of these core and $\mathrm{H} 1$ human histone genes have been reported previously $(10,40,41)$. (B) Northern blot analysis of total cellular H2A, $\mathrm{H} 2 \mathrm{~B}$, and $\mathrm{H} 4$ histone mRNAs isolated from adenovirus and mock-infected HeLa cells. Samples ( 25 and $50 \mu \mathrm{g})$ of total cellular RNA from mock-infected and adenovirus-infected HeLa cells were fractionated electrophoretically in $1.5 \%$ (wt/vol) aragose-6\% (wt/vol) formaldehyde gels and transferred to nitrocellulose. Filters were hybridized to ${ }^{32} \mathrm{P}$-labeled (nick-translated) human histone DNA (H2A $+\mathrm{H} 2 \mathrm{~B}$ [pFF435B] and $\mathrm{H} 4$ [pFO108A]) and hybrids were visualized by autoradiography. Analysis of the total cellular RNAs indicated that yields were greater than $90 \%$ in all samples, circumventing uncertaintities in quantitation because of loss or redistribution of RNA that can occur during purification, for example, through nuclease activity. (C) Northern blot analysis of total cellular, nuclear, and cytoplasmic H4 histone mRNAs isolated from adenovirus and mock-infected HeLa cells. Samples $(50 \mu \mathrm{g})$ of nuclear, cytoplasmic, or total cellular RNA from mock-infected and adenovirus-infected HeLa cells were fractionated electrophoretically in $1.5 \%$ (wt/vol) agarose-6\% (wt/vol) formaldehyde gels and transferred to nitrocellulose. Filters were hybridized to ${ }^{32}$ P-labeled (nick-translated) human $\mathrm{H} 4$ histone DNA (pFO108A), and hybrids were visualized by autoradiography. (D) Northern blot analysis of total cellular $\mathrm{H} 3$ histone mRNAs isolated from adenovirus- and mock-infected HeLa cells. Samples $(50 \mu \mathrm{g})$ of total cellular RNA from mock-infected and adenovirus-infected HeLa cells were fractionated electrophoretically in $1.5 \%(\mathrm{wt} / \mathrm{vol})$ agarose-6\% (wt/vol) formaldehyde gels and transferred to nitrocellulose. Filters were hybridized to ${ }^{32} \mathrm{P}$-labeled (nicktranslated) human $\mathrm{H} 3$ histone DNA (pFF435C), and hybrids were visualized by autoradiography. 
Total cellular RNA was prepared from uninfected and Ad2infected HeLa cells harvested $18 \mathrm{~h}$ after infection, fractionated electrophoretically, transferred to nitrocellulose, and hybridized to ${ }^{32} \mathrm{P}$-labeled cloned human histone genes (Fig. 1A). The results of one such experiment are shown in Fig. 1 (panels B to D). Quantitation (see above) of these and similar RNA blots established that the concentrations of the core histone mRNA species were reduced coordinately to $90 \%$ of the control value by $18 \mathrm{~h}$ after infection. Cellular DNA synthesis was also inhibited to $90 \%$ or greater under these conditions of infection (see, for example, Fig. 3).

The drastic reductions in steady-state concentrations of total core histone mRNA species during the late phase of adenovirus infection (Fig. $1 B$ and D) were in marked contrast to previous observations: seven human mRNA species, including those encoding actin, tubulin and dihydrofolate reductase, have been reported to be unchanged or only slightly decreased in concentration during the late phase of adenovirus infection of HeLa cells $(3,55$; unpublished data). Simian virus 40 early cytoplasmic mRNA species made in simian virus 40-transformed human cells were, however, also reduced to barely detectable steady-state levels after Ad2 infection, a response that reflects inhibition of appearance in the cytoplasm of newly synthesized simian virus 40 mRNA and the short turnover time $(40$ to $60 \mathrm{~min})$ of these sequences in uninfected cells (16). To investigate whether the low concentrations of total core histone mRNA species (Fig. 1) were the result of a similar phenomenon, the levels of nuclear and cytoplasmic species were compared. Both the nuclear and cytoplasmic representation of histone mRNA species declined $90 \%$ in infected cells compared with mockinfected cells (Fig. 1C). Such a loss of nuclear histone RNA species after adenovirus infection must reflect a virusinduced perturbation of some early step in histone mRNA biogenesis.

HeLa cells that had not been infected with Ad2 exhibited virtually unchanged concentrations of total histone mRNA species throughout an 18-h period (Fig. 2), demonstrating that the reduced concentrations shown in Fig. 1 were indeed induced by Ad 2 infection rather than by the manipulations to which the cells had been subjected.

Expression of histone and adenoviral genes at various times after Ad2 infection. To gain further insight into the mechanisms mediating inhibition of human histone gene expression during productive $\mathrm{Ad} 2$ infection and to investigate the relationship of this phenomenon to inhibition of cellular DNA and protein synthesis, we next carried out a systematic examination of these parameters as a function of the period of infection.

Shown in the Fig. 3A are the results of hybridization of total DNA, labeled with $\left[{ }^{3} \mathrm{H}\right]$ thymidine for 60 -min intervals, from mock- or Ad2-infected cells after various periods of infection of exponentially growing cells to Ad2 DNA bound to nitrocellulose filters. In this experiment, some viral DNA synthesis could be detected as early as $4 \mathrm{~h}$ after infection, and the amount of viral DNA increased rapidly thereafter, eventually representing $96 \%$ of the newly synthesized DNA. This pattern is typical of infections we have performed at multiplicities of $100 \mathrm{PFU} /$ cell. As expected from previous studies $(17,23)$, cellular DNA synthesis was rapidly inhibited between 4 and $12 \mathrm{~h}$ after infection and contributed less than $5 \%$ of the newly made DNA by $21 \mathrm{~h}$ after infection.

The synthesis of histone polypeptides was inhibited to some 30 to $40 \%$ of the control values by $8 \mathrm{~h}$ after infection and was inhibited completely by the latest period of infection examined (Fig. 3B). A typical set of labeled nuclear polypep-

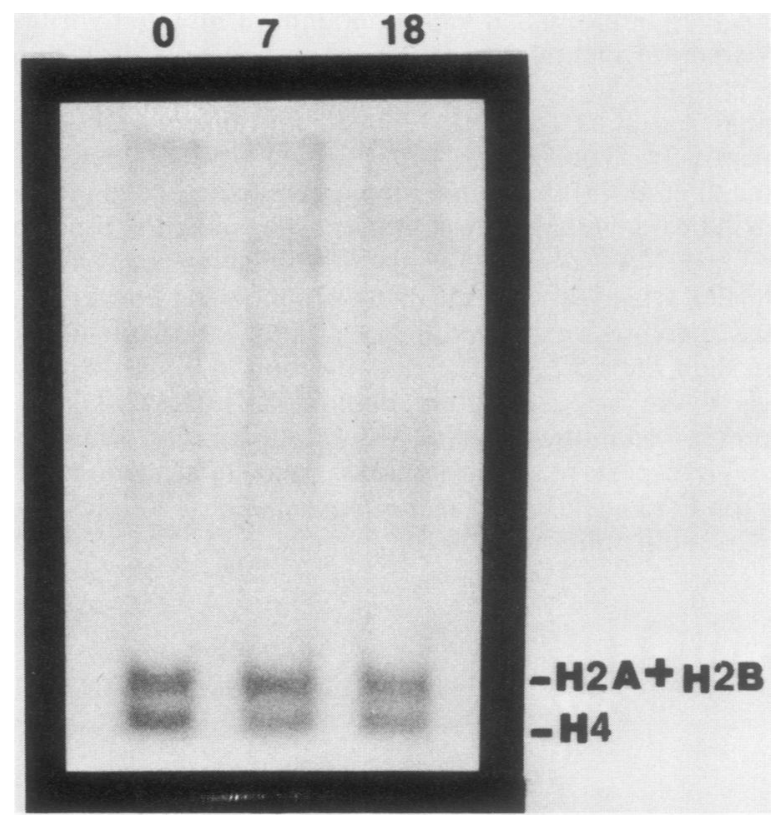

FIG. 2. Northern blot analysis of total cellular H2A, H2B, and $\mathrm{H} 4$ histone mRNAs isolated at various times after mock infection of HeLa cells. Samples $(50 \mu \mathrm{g})$ of total cellular RNA were fractionated electrophoretically as described in the legend to Fig. $1 \mathrm{~B}$ and hybridized to ${ }^{32} \mathrm{P}$-labeled human histone DNA (H2A $+\mathrm{H} 2 \mathrm{~B}$ [pFF435B] and $\mathrm{H} 4$ [pFF108A]), and hybrids were visualized by autoradiography.

tides from an independent experiment is shown in the insert in Fig. 3B to illustrate the synthesis of virus-specific proteins and inhibition of synthesis of other cellular proteins. During the early phase of infection, the only prominent viral polypeptide that could be detected was the 72-kilodalton DNAbinding protein encoded by region $\operatorname{E} 2 \mathrm{~A}(27,28)$, whereas the late phase was characterized by the synthesis of large quantities of viral structural polypeptides and their accumulation within the nucleus.

In all experiments we performed, inhibition of histone synthesis was progressive and occurred at the same rate as the inhibition of other cellular proteins, as also observed (5) in previous, less detailed studies. Not surprisingly, inhibition was more rapid in cells infected at higher multiplicities of virus. However, inhibition of histone protein synthesis did not exactly parallel the inhibition of cellular DNA synthesis (Fig. 3A and B; see Fig. 8) as it does when uninfected cells are treated with DNA synthesis inhibitors $(1,4,6,7,9,13$, $20-22,24,32-36,38,39,42,44,45)$; rather, from $4 \mathrm{~h}$ after Ad2 infection inhibition of histone protein synthesis lagged behind inhibition of cellular DNA synthesis.

The expression of two adenoviral genes was examined by run-off transcription in isolated nuclei purified from nuclei harvested after increasing intervals of infection. The ${ }^{32} \mathrm{P}$ labeled RNA was hybridized to nitrocellulose filters to which cloned restriction endonuclease fragments of $\mathrm{Ad} 2$ DNA had been transferred, and the hybridization was quantitated by densitometry. The results obtained are illustrated with 12-h RNA in the insert in Fig. 4. Transcription of E1A sequences, assayed by hybridization to $\mathrm{HpaI}$ fragment $\mathrm{E}$ (0 to 4.36 map units), could be detected at the earliest period examined, $4 \mathrm{~h}$ after infection (Fig. 4). At this time, no transcripts complementary to HindIII fragment D (38.15 to 

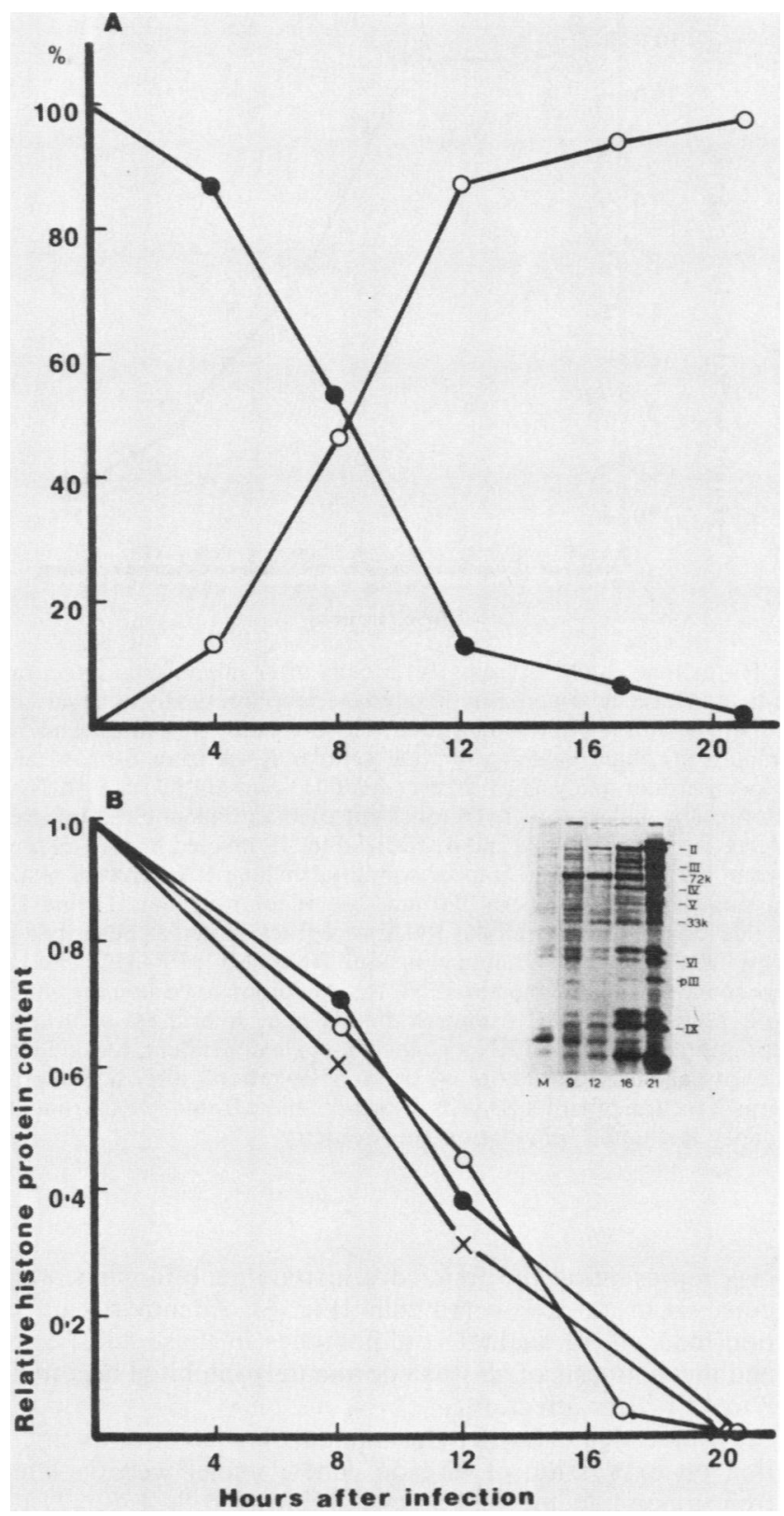

FIG. 3. Inhibition of cellular DNA and histone protein synthesis in Ad2-infected cells. Portions of mock-infected or of Ad2-infected HeLa cells (multiplicity of infection, 100 PFU per cell) withdrawn after various periods of infection were labeled with $\left[{ }^{3} \mathrm{H}\right]$ thymidine or $\left[{ }^{3} \mathrm{H}\right]$ leucine, and total DNA or protein extracts, respectively, were prepared as described in the text. (A) Incorporation of $\left[{ }^{3} \mathrm{H}\right]$ thymidine into viral and cellular DNA. ${ }^{3} \mathrm{H}$-labeled DNA was hybridized to Ad2 DNA immobilized on nitrocellulose filters as described in the text. Under the conditions used, blank filters or those carrying pBR322 DNA bound 0 to $1.9 \%$ of the input DNA. Labeled DNA from mock-infected cells gave no hybridization above background to Ad2 DNA. Each set of hybridization reactions included a positive control, in which $\left[{ }^{3} \mathrm{H}\right]$ thymidine-labeled Ad2 DNA was hybridized to establish that the highest concentrations of filter-bound Ad2 were indeed saturating; the saturation values obtained in such control experiments ranged from 91.1 to $99 \%$ hybridization. The value was 99\% in the experiment shown. The percentages of viral and cellular DNA sequences are shown by $\bigcirc$ and $\bigcirc$, respectively. (B) Inhibition of histone protein synthesis. $\left[{ }^{3} \mathrm{H}\right]$ leucine-labeled proteins recovered from a constant number of nuclei were resolved by electrophoresis,

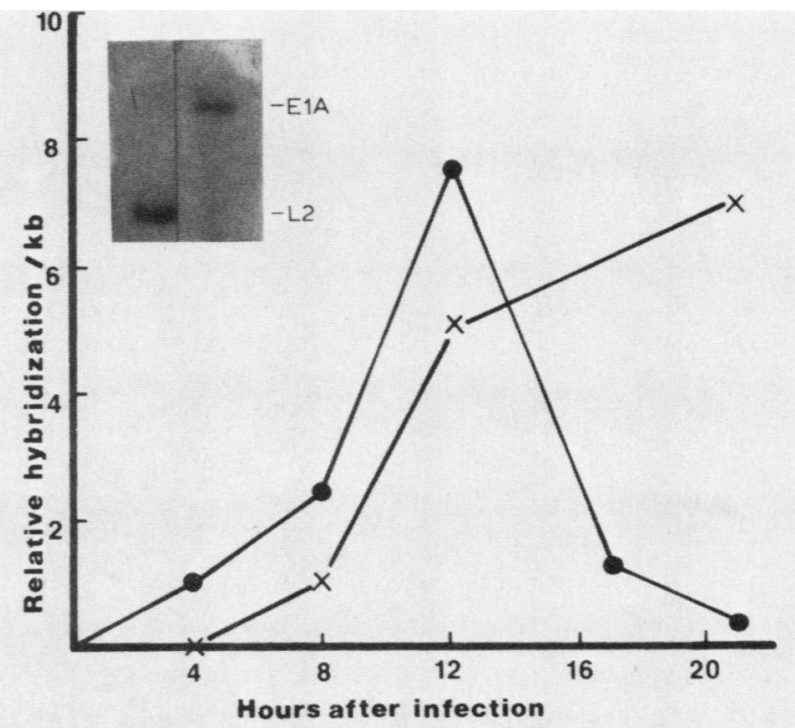

FIG. 4. Transcription of adenoviral early and late RNA sequences in isolated nuclei. Nuclei isolated from uninfected or Ad2infected cells at the intervals shown in the figure were permitted to complete transcription in the presence of $\left[\alpha-{ }^{32} \mathrm{P}\right] \mathrm{GTP}$ as described in the text. The infected culture was the same as that used in the experiments shown in Fig. 3. The labeled RNA was hybridized to cloned restriction endonuclease fragments of Ad2 DNA (see the text). An example of the results obtained, in this case with 12-h RNA, is shown in the autoradiogram (exposed to Kodak X/AR film at $-70^{\circ} \mathrm{C}$ for 3 days) at the top left of the figure. The extent of hybridization was estimated as described in the text and is expressed as relative hybridization per kilobase of transcript. Hybridization to DNA fragments that comprise the E1A gene and predominantly $\mathrm{L} 2$ sequences is represented by 0 and $\times$, respectively.

50.96 map units), which includes no early genes but sequences of the major late transcriptional unit, were produced. Transcription of E1A increased to a maximum at $12 \mathrm{~h}$ after infection and then declined sharply. By contrast, transcription of late sequences, first detected at $8 \mathrm{~h}$ after infection (after the onset of viral DNA replication; Fig. 3A), increased steadily throughout the period examined.

Having established the temporal patterns of adenoviral gene expression and replication and of inhibition of cellular DNA and protein synthesis, we examined the levels of core and $\mathrm{H} 1$ histone mRNA species throughout infection by RNA blot analysis of total cellular RNA preparations by using a series of ${ }^{32} \mathrm{P}$-labeled cloned human histone genes as hybridization probes. For purposes of comparison, individual RNA blots were hybridized with the following combinations of radiolabeled human histone genes: $\mathrm{H} 4(\mathrm{pFO} 108 \mathrm{~A})+\mathrm{H} 2 \mathrm{~A}-$ H2B (pFF435B) (Fig. 5A); H4 (pFO108A) + H3 (pFF435C) (Fig. 5B); H1 (pFNC16) $+\mathrm{H} 3$ (pFF435C) (Fig. 5C). Al-

and the amount of labeled histones was determined after fluorography as described previously (5). The insert shows a fluorogram of such a gel to which samples from an independent infection were applied to illustrate the typical course of infection under these conditions. Viral structural and nonstructural proteins are designated by Roman numerals and apparent molecular weight, respectively. The amounts of labeled $\mathrm{H} 3(\mathrm{O}), \mathrm{H} 2 \mathrm{~A}+\mathrm{H} 2 \mathrm{~B}(\mathrm{O})$, and $\mathrm{H} 4(\times)$ as fractions of the mock-infected control values are shown. 

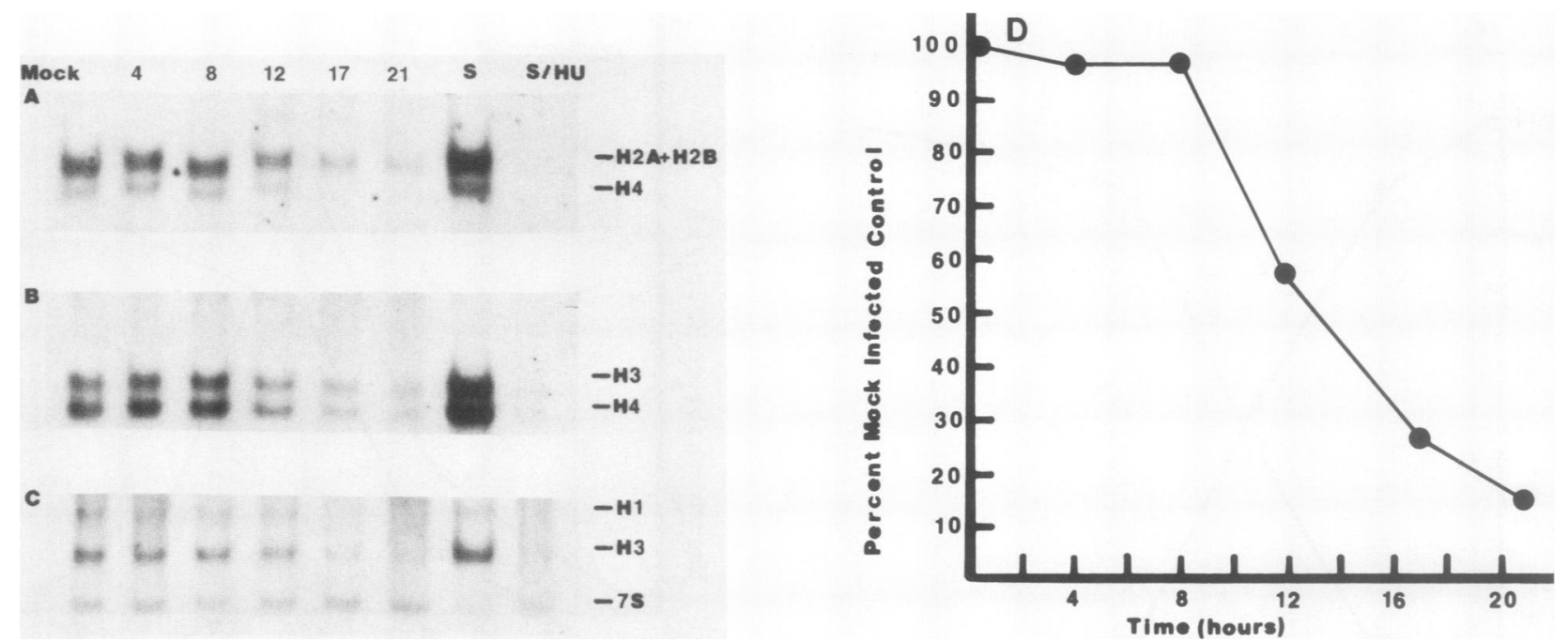

FIG. 5. (A) Northern blot analysis of total cellular H2A, H2B, and H4 histone mRNAs from HeLa cells after adenovirus infection. Samples $(50 \mu \mathrm{g})$ total cellular RNA from mock-infected and adenovirus-infected HeLa cells were fractionated electrophoretically as described in the legend to Fig. 1B, transferred to nitrocellulose and hybridized to ${ }^{32} \mathrm{P}$-labeled human histone DNA (H2A + $\mathrm{H} 2 \mathrm{~B}$ [pFF435B] and $\mathrm{H} 4$ [pFO108A]), and hybrids were visualized by autoradiography. For comparison, 50- $\mu$ g samples of total cellular RNA from S-phase and hydroxyurea-treated S-phase HeLa cells were analyzed similarly. (B) Northern blot analysis of total cellular H3 and H4 histone mRNAs isolated from HeLa S3 cells after adenovirus infection. Samples $(50 \mu \mathrm{g})$ of total cellular RNA from mock-infected and adenovirus-infected HeLa cells were fractionated as described in the legend to Fig. $1 \mathrm{~B}$, transferred to nitrocellulose and hybridized to ${ }^{32} \mathrm{P}$-labeled human histone DNA (H3 [pFF435C] and $\mathrm{H} 4$ [pFO108A]), and hybrids were visualized by autoradiography. For comparison, total cellular RNA from S-phase (S) and hydroxyurea-treated S-phase (S/HU) HeLa cells were analyzed similarly. (C) Northern blot analysis of total cellular H1 and $\mathrm{H} 3$ histone mRNAs isolated from HeLa cells after adenovirus infection. Samples $(50 \mu \mathrm{g})$ of total cellular RNA were fractionated as described in the legend to Fig. 1B and transferred to nitrocellulose and filters were hybridized to ${ }^{32}$ P-labeled human histone DNA (H3 [pFF435C] and H1 [pFNC16]), and hybrids were visualized by autoradiography. The human genomic segment cloned in pFNC16, in addition to containing an $\mathrm{H} 1$ histone gene, contains a highly repeated sequence which hybridized to a 7S RNA species. Although the H1 gene hybridizes to mRNA represented predominantly during the $S$ phase of the cell cycle (36), the representation of the 7S RNA is not cell-cycle dependent, and cellular levels of the 7S RNA are not reduced after inhibition of DNA replication by chemical inhibitors (4) or, as shown here, after adenovirus infection. (D) Cellular levels of core and $\mathrm{H} 1$ histone mRNAs after adenovirus infection of HeLa S3 cells. Northern blots from the experiments shown in Fig. 5A through $\mathrm{C}$ were quantitated by scanning microdensitometry and liquid scintillation spectrometry.

though an adenovirus-induced decrease in the representation of histone mRNA species was observed, reduction of histone mRNA levels was not as rapid as the inhibition of either cellular DNA or histone protein synthesis. For example, at 8 $\mathrm{h}$ after infection, histone protein and cellular DNA synthesis were reduced to ca. 60 to $70 \%$ and $55 \%$, respectively, of the levels observed in mock-infected cells (Fig. 3), whereas a significant reduction in core or $\mathrm{H} 1$ histone mRNA concentration was not observed at this time (Fig. 5D). Rather, histone mRNA levels first decreased at $12 \mathrm{~h}$ after infection and by $21 \mathrm{~h}$ were reduced to approximately the levels observed when HeLa cell DNA replication had been blocked by hydroxyurea (Fig. 5A through C).

Multiple histone mRNA subspecies which are encoded in different genes have been identified in HeLa cells $(29,30)$ and sea urchins (19). Coordinate regulation of multiple HeLa S3 cell core histone mRNAs, mediated both transcriptionally and post-transcriptionally, has been observed during the cell cycle $(4,21,34,35)$. To determine whether the representation of specific HeLa cell histone mRNA subspecies was differentially influenced by adenovirus infection, we labeled $\mathrm{HeLa}$ cells with $\left[{ }^{3} \mathrm{H}\right]$ uridine for 2 -h periods at various times after infection. Total cellular RNA preparations $(300 \mu \mathrm{g})$ were hybridized to filter-immobilized cloned histone genes ( $50 \mu \mathrm{g}$ per filter). The RNA was eluted, resolved by electrophoresis in denaturing polyacrylamide gels, and visualized by fluorography (34). More than 13 histone mRNA subspe- cies representing the four core histone gene families were detected in mock-infected cells (Fig. 6). Adenovirus infection induced no qualitative differences in these subspecies and the synthesis of all was coordinately inhibited beginning 8 to $12 \mathrm{~h}$ after infection.

To investigate further the influence of adenovirus infection on expression of histone genes, nuclei were isolated from mock-infected HeLa cells and from cells 4, 8, 12, 17, and $21 \mathrm{~h}$ after infection and permitted to complete transcription in vitro as described above. The radiolabeled transcripts were hybridized to nitrocellulose filters to which human histone DNA fragments had been transferred after electrophoretic fractionation. Adenovirus infection induced an inhibition of histone gene transcription (Fig. 7A). The time course and extent of inhibition of transcription were not significantly different from those observed for virus-induced inhibition of HeLa cell DNA synthesis (compare Fig. 7B and 3A).

\section{DISCUSSION}

We have presented evidence that Ad2 infection of HeLa cells induces profound inhibition of histone gene expression; the influence of infection on several parameters of histone gene expression is summarized in Fig. 8. The time course and extent of inhibition are similar for both cellular DNA synthesis and transcription of histone genes, implying that the initial effect of adenovirus infection on expression of 


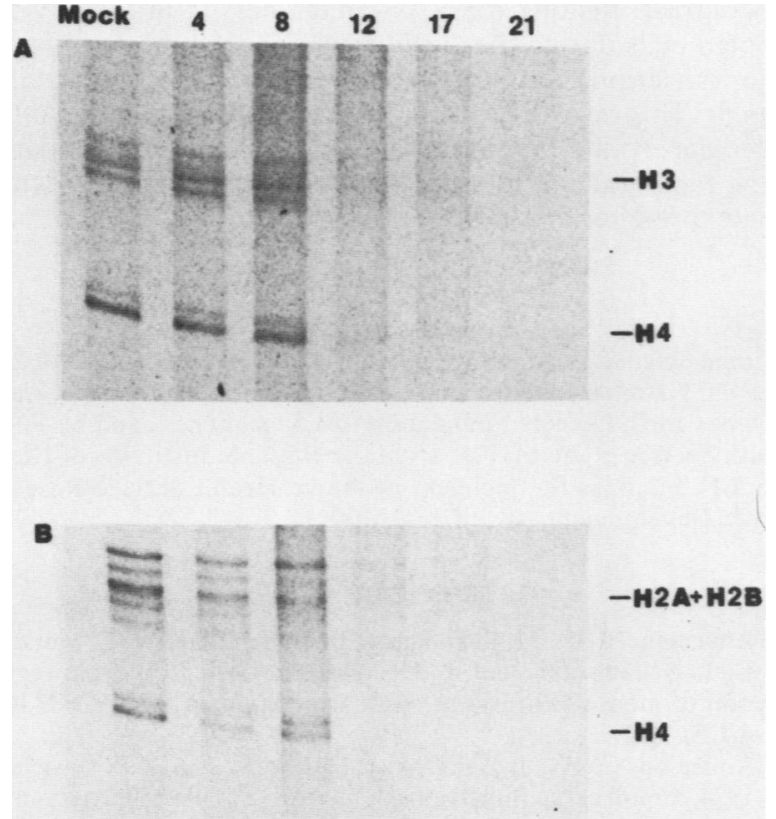

FIG. 6. (A) Electrophoretic resolution of ${ }^{3} \mathrm{H}$-labeled $\mathrm{H} 3$ and $\mathrm{H} 4$ histone mRNAs synthesized in intact HeLa cells after adenovirus infection. $\left[{ }^{3} \mathrm{H}\right]$ uridine-labeled total cellular RNA preparations labeled at the times indicated were hybrid selected with filterimmobilized plasmid DNA (H3 [pFF435C] and $\mathrm{H} 4$ [pFO108A]). Eluted RNAs were electrophoretically fractionated in denaturing $6 \%(\mathrm{wt} / \mathrm{vol})$ polyacrylamide-50\% urea gels and visualized by fluorography as described in the text. (B) Electrophoretic resolution of ${ }^{3} \mathrm{H}$-labeled $\mathrm{H} 2 \mathrm{~A}, \mathrm{H} 2 \mathrm{~B}$, and $\mathrm{H} 4$ histone mRNAs synthesized in intact HeLa cells after adenovirus infection. $\left[{ }^{3} \mathrm{H}\right]$ uridine-labeled total cellular RNA preparations labeled at the times indicated were hybrid selected with filter-immobilized plasmid DNA (H2A $+\mathrm{H} 2 \mathrm{~B}$ [pFF435B] and $\mathrm{H} 4$ [pFO108A]). Eluted RNAs were electrophoretically fractionated in denaturing $6 \%(\mathrm{wt} / \mathrm{vol})$ polyacrylamide-50\% urea gels and visualized by fluorography as described in the text.

histone genes may be transcriptionally mediated. However, the maintenance of unaltered levels of histone mRNA species until $8 \mathrm{~h}$ after infection, when histone transcription as well as histone protein synthesis are significantly reduced, suggests that histone gene expression is also regulated posttranscriptionally in adenovirus-infected cells.

The availability of histone mRNA does not appear to be the primary factor limiting the ability of adenovirus-infected HeLa cells to synthesize histone proteins (Fig. 8). Moreover, the assessment of the levels of a series of histone mRNA subspecies (Fig. 6) established that expression of at least 13 histone genes is coordinately inhibited after adenovirus infection. Thus, the partial inhibition of histone mRNA and protein synthesis that characterize the intermediate period of infection do not reflect a complete inhibition of expression of only a subset of human histone genes. It therefore seems most reasonable to postulate that translation of persisting histone mRNA species is inhibited in adenovirus-infected cells. It is, indeed, well established that polyadenylate-containing RNA preparations from cells harvested during the late phase of infection direct the synthesis in in vitro translation systems of cellular proteins that are not made in infected cells (see, for example, references 2, 28, and 33). Moreover, Babich et al. (3) have shown that Ad2infected cells contain unaltered levels of an actin mRNA, fully translatable in vitro, but which cannot be utilized by the infected cells translational machinery. The coordinate inhibition of synthesis of histones and other cellular proteins (Fig. $3 \mathrm{~B})(5)$ argues strongly for this interpretation.

Although translational inhibition may be common to histone and other cellular gene products, additional consequences of adenovirus infection for histone gene expression differ from those described previously. Transcription of the majority of cellular mRNA sequences continues during the late phase of infection, but the newly synthesized cellular mRNA fails to enter the cytoplasm $(3,5,16,55)$. By

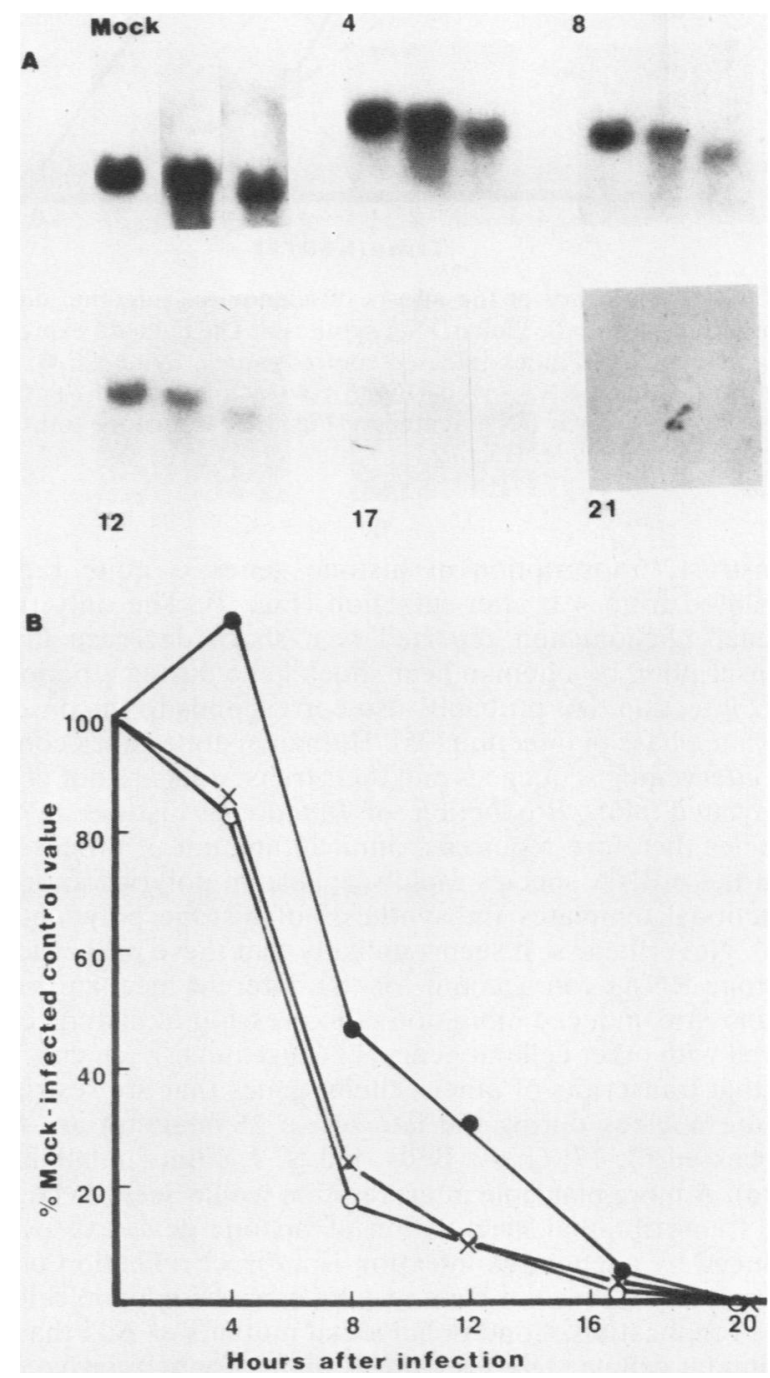

FIG. 7. Transcription of histone RNA in nuclei isolated from Ad2-infected cells. The 32P-labeled RNA synthesized in isolated nuclei described in the legend to Fig. 4 was hybridized to nitrocellulose filters carrying cloned human histone genes $\mathrm{H} 3, \mathrm{H} 2 \mathrm{~A}+\mathrm{H} 2 \mathrm{~B}$. and $\mathrm{H} 4$ in tracks 1 to 3 , respectively, of each filter shown in part A. These autoradiograms were obtained by exposure of the filters to Kodak X/AR film for 3 days at room temperature (panels Mock to 17 h) or for 2 days in the presence of an intensifying screen at $-70^{\circ} \mathrm{C}(21$ h). The levels of hybridized histone RNA were estimated by densitometry of exposures made in the absence of intensifying screens and are expressed in part $B$ as percentages of the mockinfected control values. Hybridization to $\mathrm{H} 3-, \mathrm{H} 2 \mathrm{~A}+\mathrm{H} 2 \mathrm{~B}-$, and H4-containing DNA fragments is shown by $\bullet, O$, and $\times$, respectively. 


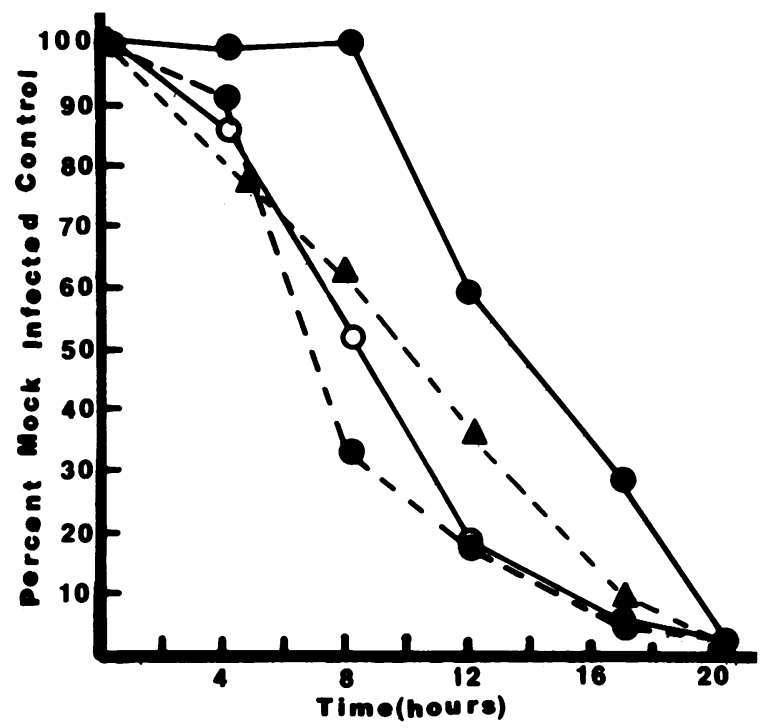

FIG. 8. Summary of the effects of adenovirus infection on histone expression and cellular DNA synthesis. The data are expressed as a percentage of mock-infected control values. Symbols: $\bullet$, core and $\mathrm{H} 1$ histone mRNA levels (Fig. 5); $\Delta$, histone protein synthesis (Fig. 3B); O, cellular DNA synthesis (Fig. 3A); $\bullet$, histone transcription in isolated nuclei (Fig. 7).

constrast, transcription of histone genes is quite rapidly inhibited from $4 \mathrm{~h}$ after infection (Fig. 7). The only other similar phenomenon reported is a sharp decrease in the transcription of a human heat-shock gene during a period of Ad2 infection that probably also corresponds to the onset of the late phase of infection (25). Human histone genes contain no intervening sequences and their transcripts are not polyadenylated (46). Production of functional histone mRNA species therefore requires a minimal amount of processing, and the mRNA species rapidly appear in polyribosomes as functional templates for synthesis of histone polypeptides (46). Nevertheless, it seems unlikely that these properties of histone RNAs can account for the different mechanisms of adenovirus-induced inhibition of expression of histone compared with other cellular genes, because it has been concluded that transcripts of other cellular genes that are restricted to the nucleus during the late phase of infection are fully processed $(3,17$; G. A. Beltz and S. J. Flint, unpublished data). A more plausible interpretation would seem to be that the transcriptional inactivation of histone gene expression induced by adenovirus infection is a direct reflection of the normal dependence of histone gene expression upon cellular DNA replication. Conditional lethal mutants of Ad5 that fail to inhibit cellular DNA synthesis under nonpermissive conditions of infection (S. L. Ho and J. Williams, personal communication) should permit this hypothesis to be tested.

Nevertheless, the data presented here also suggest that there may be differences in the mechanism(s) whereby histone gene expression is prevented in adenovirus-infected cells compared with the inhibition induced when cellular DNA replication is blocked by such drugs as hydroxyurea, cytosine arabinoside, methotrexate, or aphidiolin. It is well established that exposure of cells to these inhibitors brings about a rapid, dose-dependent coordinate inhibition of core and $\mathrm{H} 1$ histone RNA and protein synthesis, as well as a concomitant destabilization of core and $\mathrm{H} 1$ histone mRNA species $(1,4,6,7,9,13.20-22,24,32-36,38,39,42,44,45)$.
By contrast, histone mRNA species persist in adenovirusinfected cells during the early period of inhibition of histone gene transcription and of histone protein and cellular DNA (Fig. 8). This result may be indicative of an uncoupling of the molecular events that in uninfected cells are the foundation of the temporal and functional relationship between histone gene expression and DNA replication.

\section{ACKNOWLEDGMENTS}

These studies were supported by grant PCM18177 from the National Science Foundation, Public Health Service grant GM32010 from the National Institutes of Health, grant 1-813 from the March of Dimes Birth Defects Foundation to J.S. and G.S., and by Public Health Service grant AI17265 from the National Institutes of Health to S.J.F. S.J.F. is the recipient of Public Health Service Research Career Development Award K04AI00441.

\section{LITERATURE CITED}

1. Alterman, R.-B., M. S. Ganguly, D. H. Schultze, W. F. Marzluff, C. L. Schildkraut, and A. I. Skoultchi. 1984. Cell cycle regulation of mouse $\mathrm{H} 3$ histone mRNA metabolism. Mol. Cell. Biol. 4:123-132.

2. Anderson, C. W., J. B. Lewis, J. F. Atkins, and R. F. Gesteland. 1974. Cell-free synthesis of adenovirus 2 proteins programmed by fractionated mRNA: a comparison of polypeptide products and mRNA lengths. Proc. Natl. Acad. Sci. U.S.A. 71:27562760.

3. Babich, A., L. T. Feldman, J. R. Nevins, J. E. Darnell, and C. Weinberger. 1983. Effects of adenovirus on metabolism of specific host mRNAs: transport control and specific translational discrimination. Mol. Cell. Biol. 3:1212-1221.

4. Baumbach, L. L., F. Marashi, M. Plumb, G. Stein, and J. Stein. 1984. Inhibition of DNA replication co-ordinately reduces cellular levels of core and $\mathrm{H} 1$ histone mRNAs: requirement for protein synthesis. Biochemistry 23:1618-1625.

5. Beltz, G., and S. J. Flint. 1979. Inhibition with HeLa protein synthesis during adenovirus infection: restriction of cellular messenger RNA sequences to the nucleus. J. Mol. Biol. 131:353-373.

6. Borun, T. W., M. D. Scharff, and E. Robbins. 1967. Rapidlylabeled polyribosome-associated RNA having the properties of histone messenger. Proc. Natl. Acad. Sci. U.S.A. 58:19771983.

7. Borun, T. W., F. Gabrielli, D. Ajiro, A. Zweidler, and C. Baglioni. 1975. Further evidence for transcriptional and translational control of histone messenger RNA during the HeLa S3 cell cycle. Cell 4:59-67.

8. Botchan, M. B., W. Topp, and J. Sambrook. 1976. The arrangement of simian virus $\mathbf{4 0}$ sequences in DNA of transformed cells. Cell 9:269-287.

9. Breindl, L. M., and D. Gallwitz. 1974. Effects of cordycepin, hydroxyurea and cycloheximide on histone mRNA synthesis in synchronized HeLa cells. Mol. Biol. Reps. 1:263-268.

10. Carozzi, N., F. Marashi, M. Plumb, S. Zimmerman, A. Zimmerman, J. R. E. Wells, G. Stein, and J. Stein. 1984. Clustering of human $\mathrm{H} 1$ and core histone genes. Science, in press.

11. Castiglia, C. L., and S. J. Flint. 1983. Effects of adenovirus infection on rRNA synthesis and maturation in HeLa cells. Mol. Cell. Biol. 3:662-671.

12. Chiu, I.-M., and W. F. Marzluff. 1982. Uncoordinate synthesis of histone $\mathrm{H} 1$ in cells arrested in the G1 phase. Biochim. Biophys. Acta 699:173-182.

13. Delegeane, A. M., and A. D. Lee. 1982. Coupling of histone and DNA synthesis in the somatic cell cycle. Science 215:79-81.

14. Flint, S. J. 1982. Expression of adenoviral genetic information in productively-infected cells. Biochim. Biophys. Acta 651:175208.

15. Flint, S. J., P. H. Gallimore, and P. A. Sharp. 1975. Comparison of viral RNA sequences in adenovirus 2 transformed and lytically infected cells. J. Mol. Biol. 96:47-68.

16. Flint, S. J., G. A. Beltz, and D. Linzer. 1983. The synthesis and 
processing of SV40-specific RNA in adenovirus-infected, SV40transformed human cells. J. Mol. Biol. 167:335-359.

17. Ginsberg, H. S., L. J. Bello, and A. J. Levine. 1967. Control of biosynthesis of host macromolecules in cells infected with adenovirus, p. 547-572. In J. S. Colter and W. Paranchych (ed.), The molecular biology of viruses. Academic Press, Inc., New York.

18. Groppi, V. E., and P. Coffino. 1980. G1 and S phase mammalian cells synthesize histones at equivalent rates. Cell 21:195-204.

19. Grunstein, M. 1978. Hatching in the sea urchin Lytechinus pictus is accompanied by a shift in histone $\mathrm{H} 4$ gene activity. Proc. Natl. Acad. Sci. U.S.A. 75:4135-4139.

20. Heintz, N., M. Zernik, and R. G. Roeder. 1981. The structure of the human histone genes: clustered but not tandemly repeated. Cell 24:661-666.

21. Heintz, N., H. L. Sive, and R. G. Roeder. 1983. Regulation of human histone gene expression: kinetics of accumulation and changes in the rate of synthesis of the half-lives of individual histone mRNAs during the HeLa cell cycle. Mol. Cell. Biol. 3:539-550.

22. Hereford, L. M., M. A. Osley, J. R. Ludwig, and C. S. McLaughlin. 1981. Cell cycle regulation of yeast histone mRNA. Cell 24:367-375.

23. Hodge, L. D., and M. D. Scharfi. 1969. Effect of adenovirus on host cell DNA synthesis in synchronized cells. Virology 37:554564.

24. Jacobs-Lorena, M., F. Gabrielli, T. W. Borun, and C. Baglioni. 1973. Studies on the transcriptional control of histone synthesis. Biochim. Biophys. Acta 324:275-281.

25. Kao, H.-T., and J. R. Nevins. 1983. Transcriptional activation and subsequent control of the human heat shock gene during adenovirus infection. Mol. Cell. Biol. 3:2058-2065.

26. Lennox, R. W., and L. W. Cohen. 1983. The histone H1 complements of dividing and non-dividing cells of the mouse. J. Biol. Chem. 258:262-268.

27. Levine, A. J., P. C. van der Vliet, B. Rosenwirth, J. Rabek, G. Frenkel, and M. Ensinger. 1975. Adenovirus infected cellspecific DNA binding proteins. Cold Spring Harbor Symp. Quant. Biol. 39:559-566.

28. Lewis, J. B., J. F. Atkins, P. R. Baum. R. Solem, R. F. Gesteland, and C. W. Anderson. 1976. Location and identification of the genes for adenovirus type 2 early polypeptides. Cell 7:141-151.

29. Lichtler, A. C., S. Detke, I. R. Phillips, G. S. Stein, and J. L. Stein. 1980. Multiple forms of $\mathrm{H} 4$ histone mRNA in human cells. Proc. Natl. Acad. Sci. U.S.A. 77:1942-1946.

30. Lichtler, A. C., F. Sierra, S. Clark, J. R. E. Wells, J. L. Stein, and G. S. Stein. 1982. Multiple $\mathrm{H} 4$ histone mRNAs of $\mathrm{HeLa}$ cells are encoded in different genes. Nature (London) 298:195198.

31. Maniatis, T., A. Jeffrey, and D. B. Kleid. 1975. Nucleotide sequence of rightward operator of $\lambda$. Proc. Natl. Acad. Sci. U.S.A. 72:1184-1188.

32. Marashi, F., L. Baumbach, R. Rickles, F. Sierra, J. Stein, and G. Stein. 1982. Histone proteins in HeLa S3 cells are synthesized in a cell cycle stage specific manner. Science 215:683-685.

33. Paterson, B. M., B. Roberts, and E. L. Kuff. 1977. Structural gene identification and mapping by DNA-mRNA hybrid-arrested cell-free translation. Proc. Natl. Acad. Sci. U.S.A. 74:4370 4374.

34. Plumb, M., J. Stein, and G. Stein. 1983. Coordinate regulation of multiple histone mRNAs during the cell cycle in HeLa cells. Nucleic Acids Res. 11:2391-2410.

35. Plumb, M., J. Stein, and G. Stein. 1983. Influence of DNA synthesis inhibition on the coordinate expression of core histone genes during S phase. Nucleic Acids Res. 11:7927-7945.

36. Plumb, M., F. Marashi, L. Green, A. Zimmerman, S. Zimmer- man, J. Stein, and G. Stein. 1984. Cell cycle regulation of human histone H1 mRNA. Proc. Natl. Acad. Sci. U.S.A. 81:434-438.

37. Rave, N., R. Crkvenjakov, and H. Boedtker. 1979. Identification of procollagen mRNAs transferred to diazobenzyloxymethy paper from formaldehyde agarose gels. Nucleic Acids Res. 6:3359-3567.

38. Rickles, R., Marashi, F., F. Sierra, J. Wells, J. Stein, and G. Stein. 1982. Analysis of histone gene expression during the cell cycle in HeLa cells using cloned human histone genes. Proc. Natl. Acad. Sci. U.S.A. 79:749-753.

39. Robbins, E., and T. W. Borun. 1967. The cytoplasmic synthesis of histone in HeLa cells and its temporal relationship to DNA replication. Proc. Natl. Acad. Sci. U.S.A. 57:409-416.

40. Sierra, F., S. Clark, J. Wells, J. Stein, and G. Stein. 1982. Organization of human histone genes. Proc. Natl. Acad. Sci. U.S.A. 79:1795-1797.

41. Sierra, F., G. Stein, and J. Stein. 1983. Structure and in vitro transcription of a human $\mathrm{H} 4$ histone gene. Nucleic Acids Res. 11:7069-7086.

42. Sittman, D. B., R. A. Graves, and W. F. Marzluff. 1983. Histone mRNA concentrations are regulated at the level of transcription and mRNA degradation. Proc. Natl. Acad. Sci. U.S.A. 80:1849-1853.

43. Southern, E. M. 1975. Detection of specific DNA sequences among DNA fragments separated by gel electrophoresis. J. Mol. Biol. 98:504-517.

44. Spalding, J., K. Kajiwara, and G. C. Mueller. 1966. The metabolism of basic proteins in HeLa cell nuclei. Proc. Natl. Acad. Sci. U.S.A. 56:1535-1542.

45. Stein, G. S., and T. W. Borun. 1972. The synthesis of acidic chromosomal proteins during the cell cycle of HeLa S3 cells. Cell. Biol. 52:292-307.

46. Stein, G. S., S. Hochhauser, and J. L. Stein. 1979. Histone genes: their structure and control, p. 259-307. In H. Busch (ed.), The cell nucleus, vol. VII. Academic Press, Inc., New York.

47. Stein, G. S., F. Sierra, J. L. Stein, M. Plumb, F. Marashi, N. Carozzi, K. Prokopp, and L. Baumbach. 1984. Organization and expression of human histone genes, p. 397-455. In G. S. Stein, J. L. Stein, and W. F. Marzluff (ed.), Histone genes and histone gene expression. John Wiley \& Sons, Inc., New York.

48. Thimmappaya, B., C. Weinberger, R. J. Schneider, and T. Shenk. 1982. Adenovirus $V A_{I}$ RNA is required for efficient translation of viral mRNA at late times after infection. Cell 31:543-551.

49. Thomas, P. 1980. Hybridization of denatured RNA and small DNA fragments transferred to nitrocellulose. Proc. Natl. Acad. Sci. U.S.A. 77:5301-5205.

50. Tooze, J. (ed.). 1980. The molecular biology of tumor viruses. Part 2. DNA tumor viruses (2nd ed.). Cold Spring Harbor Laboratory, Cold Spring Harbor. N.Y.

51. Tullis, R. H., and H. Rubin. 1980. Calcium protects DNase 1 from proteinase $\mathrm{K}$ : a new method for removal of contaminating RNase from DNase 1. Anal. Biochem. 107:260-264.

52. Williams, J. F. 1970. Enhancement of adenovirus plaque formation on HeLa cells by magnesium chloride. J. Gen. Virol. 9:251256.

53. Wu, R. S., and W. M. Bonner. 1981. Separation of basal histone synthesis from $\mathrm{S}$ phase histone synthesis of dividing cells. Cell 27:321-330.

54. Yang, V. W., and S. J. Flint. 1979. Synthesis and processing of adenoviral RNA in isolated nuclei. J. Virol. 32:394-403.

55. Yoder, S. S., B. L. Robberson, E. J. Leys, A. G. Hook, M. AlUbaidi, K.-Y. Yeung, R. E. Kellems, and S. M. Berget. 1983. Control of cellular gene expression during adenovirus infection: induction and shut-off of dihydrofolate reductase gene expression by adenovirus type 2. Mol. Cell. Biol. 3:819-828. 